\title{
Medical History Reference Identifier
}

National Cancer Institute

\section{Source}

National Cancer Institute. Medical History Reference Identifier. NCI Thesaurus. Code C83335.

A character or string that represents a medical history event reference. 